Trinity University

Digital Commons @ Trinity

Modern Languages and Literatures Faculty

Research

Modern Languages and Literatures Department

4-2009

\title{
Time, Space, and the Question of Heroism in Sertorius
}

Nina Ekstein

TrinityUniversity, nekstein@trinity.edu

Follow this and additional works at: http://digitalcommons.trinity.edu/mll_faculty

Part of the Modern Languages Commons

\section{Repository Citation}

Ekstein, N. (2009). Time, space, and the question of heroism in Sertorius. Neophilologus, 93, 201-213. doi: 10.1007/ s11061-008-9118-8

This Article is brought to you for free and open access by the Modern Languages and Literatures Department at Digital Commons @ Trinity. It has been accepted for inclusion in Modern Languages and Literatures Faculty Research by an authorized administrator of Digital Commons @ Trinity. For more information, please contact jcostanz@trinity.edu. 


\title{
Time, Space, and the Question of Heroism in Sertorius
}

\author{
Nina Ekstein
}

Published online: 20 June 2008

(C) Springer Science+Business Media B.V. 2008

\begin{abstract}
This article examines the exceptional role Corneille gives to the dimensions of time and space in Sertorius, one of the playwright's later tragedies. In contrast to Corneille's general dramatic practice, in which the two dimensions are relatively neglected, here they are foregrounded and serve as a framework for Sertorius's tragedy. His relationship to time-he is essentially a man of the past to whom the future will be denied-and to space-immobilized in Nertobridge while aching to return to Rome-restricts him and prevents forward movement in either realm. Furthermore, time and space provide a vital key for unraveling the thorny issue of heroism as it pertains to both Sertorius and Pompée.
\end{abstract}

Keywords Corneille, Pierre $\cdot$ Sertorius $\cdot$ Time $\cdot$ Space $\cdot$ Heroism

Time and space are essential features of theater. Each dramatic universe is anchored by the very real parameters of performance time and performance space, coupled with the somewhat more malleable demands of referential place and time. Corneille fully appreciated the force of both the performance and the referential dimensions, and his plays customarily provide careful indicators of where the action occurs and the time elapsed. The rigors of the classical unities of time and place are a more sticky issue for the playwright, as he at times bristles against the constraints imposed upon him by the doctes. Unlike Racine, who takes the limits imposed-24 h and only one space-and makes them a vital part of his dramaturgy and his poetry, Corneille rarely places significant focus on either time or space. He does however exert time pressure on certain characters in a fair number of his plays, perhaps most strikingly in $\mathrm{Le} \mathrm{Cid,}$ Rodogune, Othon, and Suréna. Furthermore, power relationships in Corneille's plays

\footnotetext{
N. Ekstein $(\bowtie)$

Department of Modern Languages and Literatures, Trinity University, 1 Trinity Place, San Antonio, 78209, USA

e-mail: nekstein@trinity.edu
} 
on occasion involve one character imposing a deadline upon another. ${ }^{1}$ But the palpable weight of the past that dominates Andromaque or that of the future in Iphigénie is fundamentally alien to Corneille's dramatic practice. ${ }^{2}$ Place is even less central to Corneille's preoccupations than time. Nonetheless, considerations of space are interwoven into both Nicomède and Pompée, where certain characters cross frontiers into a space over which they do not have clear authority. More broadly, geographical space may be considered a necessary feature of all of Corneille's plays dealing with Roman colonization. In only one tragedy, however, does the playwright create significant tension based on the spatial isolation entailed by the unity of place: Horace, where in act 3 Camille and Sabine, and the audience along with them, are sequestered on stage, far from the action of the battle between the Horace and the Curiace. ${ }^{3}$

Sertorius is a surprising exception to Corneille's usual practice in these areas. Time and space are both central concerns and are both integrated into the play at mutiple levels: rhetoric, character, plot, and structure. In this tragedy, Corneille offers no resistance to the prescribed classical limitations, working comfortably within one space and a time span of $24 \mathrm{~h}$. Indeed, the playwright moves well beyond simple acceptance of the rules in this play to deliberately using both of these limitations to his advantage dramaturgically.

Sertorius has had a curiously checkered reception since it was first staged in 1662. It was regularly performed by the Comédie française until 1805, whereupon it disappeared from the stage until a brief revival in $1981 .{ }^{4}$ Pocock says that the tragedy "was in its day, and long after, considered one of Corneille's masterpieces" (1973, p. 118). Modern critical studies of Sertorius do not often share that opinion. A number are contentious, backing one character while denigrating another, and they usually engage the question of heroism: is Sertorius heroic? Or is Pompée? ${ }^{5}$ Clearly, questions of time and space are pertinent to discussions of heroism: is heroism immutable or can one become a hero or become unheroic? Can one be heroic in one place but not in another? Such questions have long interested Corneille: one has only to think of Horace or Auguste in Cinna. In this play, however, the issues have become more vexing. A thorough examination of the role of time and space, in that order, as well as the ways in which the two function in tandem, will provide an illuminating perspective on the play as a whole and on the particular question of heroism.

\footnotetext{
${ }^{1}$ For example, Pulchérie gives Aspar 2 days to make up his mind whether to marry Irène (Pulchérie 5.4), and Attila gives Honorie an hour to decide to marry Attila or his captain of the guards Octar (Attila 4.3).

${ }^{2}$ Phinée in Andromède claims that his past—6 years of fidelity to Adromède—gives him a right to marry her, but his argument convinces no one. In fact, perhaps ironically, Phinée loses Andromède because of spatial infidelity: he is not where he should be —on the cliff, by her side—as she awaits the monster.

${ }^{3}$ Less central, but worth mentioning, is Attila. The Hun carefully isolates the other characters during the entr'acte before act 3: Ardaric and Valamir may leave their tents only to go to Attila's, and only the women's servants may enter Honorie's and Ildione's tents. Their space is thus restricted and their interaction prevented.

${ }^{4}$ There was also a production of the play by Brigitte Jaques at the Théatre de la Commune in 1997.

${ }^{5}$ Couton (1987, p. 1446) and Stegmann (1968, p. 477) find Pompée to be the heroic figure, while McDermott (1983, p. 116) favors Sertorius. Butler, in an influential article, attacks the latter strongly, denying him all claims to heroism.
} 
Aufide's first lines in the first scene of the play are: "Quel honteux contretemps de vertu délicate/S'oppose au beau succès de l'espoir qui vous flatte" (11.17-18), spoken in reaction to Perpenna's reservations about the plan to assassinate Sertorius. The implicit ties between the words "temps" and "contretemps" allow Aufide to obliquely suggest that time may be an enemy. Indeed, all of the characters propose plans, and all look to the future to offer them a path to the realization of their dreams: for Sertorius, a triumphant return to Rome; for Perpenna, winning Viriate and capturing Sertorius's position as general; for Pompée, command of Rome; for Aristie, the return of her husband; for Viriate, a powerful and committed defender for her land. Yet as all look to the future with "espoir," "contretemps" abound.

In fact, time pressures take control of the plot and almost immediately weigh heavily on Perpenna and Sertorius. A critical moment has arrived as the curtain rises: Sertorius must decide whether to marry Viriate or Aristie, and Perpenna must choose whether to go forward with the assassination plot or not. The first scene of the play presents the most ineluctable time limit - the assassination of Sertorius is set to take place that very evening, but only Aufide seems to be fully cognizant of the time pressure involved. ${ }^{6}$ In an unusual situation of dramatic irony that will hang over the next four acts, the audience-knowing as it does that the assassination plot exists and when it is to occur-feels this specific time pressure as accutely as do the conspirators. To carry through with the plot that very evening or to have everyone involved in it eliminated (including, presumably, Aufide) is the primary time constraint that trammels Perpenna. It will be compounded by Sertorius's pressure upon him to sacrifice Viriate (IV, 3). In a balanced, albeit inverted fashion, Sertorius too operates under the pressure of making two decisions, one of which involves a specified temporal limit. First, he must choose between Aristie and Viriate, and second, Viriate, in act 4, scene 2, gives him until "demain" (1.1399) to marry her and thereby sacrifice all hope of ever returning to Rome. Sertorius is, of course, unaware of the more immediate and lethal temporal threat posed by Perpenna. Even Pompée is under time constraints, again of a double nature. First, his own ambition impels him to leave Nertobrige: he has not been successful at defeating Sertorius and the prolongued standoff between the two Roman armies does little to further the attacking general's reputation. Pompée wants to fight elsewhere and win. His primary motivation for the meeting with Sertorius is to seek an accord that would free him to depart. Second, Aristie informs Pompée that if he does not repudiate Émilie, and therefore Sylla, she will marry Sertorius ("Mais il est temps qu'un mot termine ces débats," 1.1115). ${ }^{7}$

\footnotetext{
${ }^{6}$ It is worth noting that Corneille delays specifying this time frame until 12 lines before the end of this long initial scene. Aufide says: "C'est trop craindre, et trop tard. C'est dans votre festin/Que ce soir par votre ordre on tranche son destin" (11.107-08). This delay until the end of the scene parallels Corneille's choice to delay information concerning Sylla and Émilie until the final act.

7 Kerr has written a rich and insightful article concerning time and space in Sertorius to which my own work is indebted. I disagree with her, however, when she says that Pompée is the only character who trusts time, that he "accepte la tyrannie du présent parce qu'il sait qu'elle ne durera pas. Ce qui le distingue, c'est qu'il considère le temps non pas comme un ennemi mais comme un allié” (1983, p. 25). In my opinion, he is under as much time pressure as any of the others, a situation that suggests that time is as much of a "contretemps" for him as for the other two men. What is different about Pompée is that he, unlike Sertorius or Perpenna, can be said to be in the right place at the right time.
} 
Thus a series of temporal straitjackets constrains the male characters of the play and creates an atmosphere of suspense for the audience.

The classic counter-measure in response to time pressure is delay. While perhaps the most natural response to such stress, it has the decided drawback of being profoundly unheroic. Indeed, Sertorius's close association with delay is strongly featured in Butler's scathing assessment of the character's heroic standing (1977, p. 65-66). Sertorius consciously adopts delay as a strategy in his dealings with others. Afraid of the political repercussions of choosing to marry either Aristie or Viriate and thereby rebuffing the other, Sertorius devotes act 2 to delaying a final decision. Later, in act 4, Sertorius suggests that Viriate delay any rejection of Perpenna ("Souffrez qu'un peu de temps doucement le ménage," 1.1313). In the same scene, the aging general seeks to delay marrying Viriate himself: in love with her, but loathe to offend Perpenna or to give up the sustaining hope of triumphal return to a free Rome, he attempts to put her off: "Ah! Madame, est-il temps que cette grâce éclate?" (1.1310). He then attempts to placate Perpenna by turning again to the tactic of delay, suggesting that Viriate will perhaps later want to marry Sertorius's lieutenant ("peut-être le temps la rendra moins altière," 1.1470). Even in Sertorius's description of his meeting with Pompée, he uses the language of deferral and postponement: "Il n'est pas encore temps" (1.1413). By choosing delay, Sertorius renders himself immobile.

In contrast, Perpenna seems considerably less lucid about his own desire for delay, perhaps because it pertains only to the decision about whether to have Sertorius killed; in other respects he is hungry to move forward. PerPenna twice puts off deciding whether to authorize the assassination (1.1 and 4.4). The second delay is ostensibly motivated by spatial considerations: Perpenna suggests that Aufide discuss such matters at his home, outside of the public arena of the onstage space. The audience never hears Perpenna discuss assassination; his onstage focus is either on his wounded pride caused by unrealized ambitions or his frustrated love for Viriate. The move from envy and jealousy to assassination is articulated by Aufide alone. Although Perpenna at some point must have acquiesced, on stage he does little more than shut his eyes to the time pressure and push it aside. Delay carries the same morally problematic cast for him as it does for Sertorius.

Pompée combines features of both men in this respect. In his long scene with Sertorius, Pompée advocates immediate action: let us come to an agreement now, an agreement that will lead Sylla to step down. In his own political choices and in his dealings with Aristie, Pompée has chosen tactical delay: he will patiently await the day that Sylla no longer rules Rome, and he urges Aristie to do the same. His ambition to lead Rome and his personal happiness will both wait.

All three men feel the pressure of time; all three react to varying degrees with the counter-measure of delay. The concern with heroism in this arena is perhaps misplaced, as none escape the taint of association with delay, none stand up forcefully to the pressure of time. François Lassere's observation that it is the "multitude de notations de délais qui créent tout le climat dramatique de Sertorius" (1998, p. 682) is more fair and more apt than considering the urge to delay as a negative barometer of heroism. 
It is worth observing that the female characters' stance does not involve delay at all, but rather foregrounds immediate action. Despite their relative impotence in an environment of war, the two women create several of the time pressures weighing upon the males. At the beginning of act 4 scene 2, Viriate tells Sertorius that she will marry Perpenna and prefers to do so immediately ("Dès ce même moment," 1.1227); at the end of the same scene, she give Sertorius one day to make up his own mind to marry her. Aristie tells Pompée in act 3 scene 2 that he must choose then and there whether to return to her or lose her forever (see above, 1.1115).

Another feature of time that plays a central role in Sertorius is age. While considerations of age and generation have a role in any number of Corneille's plays, nowhere, with the exception of Pulchérie, are they as crucial as here. Sertorius is growing old. Indeed, the objection has been raised more than once that Sertorius does nothing of note during the course of the play; his heroism belongs to the past (Prigent 1986, p. 399; Kerr 1983, p. 17). Aristie and Viriate contemplate marrying him but nowhere suggest a sexual component to that union. In fact, what they both want to wed is not a man, but that man's renown, his name. The word "nom" is the key defining feature of Sertorius: it leads Perpenna's soldiers to change leaders; it attracts Viriate and Aricie and makes Perpenna intensely envious; it is the essence of Sertorius's leadership and the promise of his immortality. ${ }^{8}$ In a discussion with her confidante Thamire, Viriate acknowledges that Sertorius may not live much longer:

Jouissons, en dépit de l'envie,

Des restes glorieux de son illustre vie:

Sa mort me laissera pour ma protection

La splendeur de son ombre et l'éclat de son nom. (11.465-68)

The fact that Sertorius is almost as useful to her dead as alive can be read as a signal of his impending death.

The subject of Sertorius's age comes up in his relationship to Pompée. The former reacts to Pompée's compliments by framing them modestly in terms of the difference between their ages, and thus their experience ("Le temps y fait beaucoup," 1. 802), while the latter recognizes that Sertorius's offer to serve as Pompée's lieutenant is absurd because of that very difference between them ("de pareils lieutenants n'ont des chefs qu'en idée," 1. 953). The question of Sertorius's age is most poignant in the context of his love for Viriate. He is the first to admit that his feelings are inappropriate for a man of his age ("À mon âge il sied ... mal d'aimer," 1.179). ${ }^{9}$

Thus, Sertorius is highly conscious of his age, and everyone else is as well. The frequent references to his advanced years remind us that this tragedy is about the transfer of power from one generation to the next. Sertorius is not the only "old"

\footnotetext{
${ }^{8}$ Ironically, Corneille introduces the term "nom" by its denigration in Aufide's mouth in the very first scene of the play: "L'honneur et la vertu sont des noms ridicules" (1.25), thereby problematizing the ideal he will set up just a few lines later in the same scene through Perpenna's discussion of Sertorius's great "nom."

9 The biographical resonance for Corneille of Sertorius's love has long been noted: the playwright was 56 in 1662 when the play was first performed.
} 
character; he and Sylla seem to be contemporaries. In the natural order of things, both must pass from the stage of public power and the arena of love. Sertorius must literally disappear from the stage, which he does near the end of act 4, while Syllaas we discover in act 5-has already left the public stage when the play begins. The latter's abdication, a kind of political death, is the equivalent of Sertorius's literal demise. We might even say, were not both Sertorius and Sylla so obviously aware of the precarity that age has brought to their powers, that this is a play about the young killing off and taking over from the old. If it were that simple, the play would be a comedy and we might agree with Fumaroli's assessment: "Tandis qu'une nuit funèbre et sanglante descend sur Sertorius, Pompée, le jeune Pompée, entre en triomphe sur la scène, tel un soleil levant, ralliant à lui les soldats du héros républicain, et retrouvant avec joie son épouse Aristie" (1996, p. 56). But it is Sertorius, not Pompée, who is at the center of this tragedy. ${ }^{10}$

Time has a further dimension in Sertorius, one that I will return to later because it needs to be discussed in conjunction with space: the acceleration that we find in act 5. In a cascade of scenes-eight compared to an average of 3.5 for the first four acts-lengthy deliberation gives way to a rapid series of surprising events. Time is thus fundamental to the plot through its pressures and counter-pressures, to the characterization of the three male characters, and to the structure of the play as the audience will experience it through acceleration.

Discussion of spatial considerations in this play will entail several aspects of the notion of space: onstage setting, geographical location and its metaphorical projections, and relational space. Most salient are the two geographical locations, Rome and Spain. In a number of Corneille's plays, Rome is the elsewhere to which characters refer, from whence they come, on whose behalf they act (i.e., Pompée, Nicomède, Sophonisbe, Attila), but nowhere is its, or any other place's, geographical magnetism comparable to what we find in Sertorius. Rome is frequently personified in Corneille's text; it is such a potent space that it seems capable of action and thought. Indeed, Kerr refers to Rome as "l'actant principal de la pièce" (1983, p. 21). ${ }^{11}$

For Sertorius, it is the only geographical space that matters. Despite the power and respect he enjoys in Nertobrige, despite his bombastic declaration, "Rome n'est plus dans Rome, elle est toute où je suis" (1.936), he wants nothing so much as to return to the real Rome, but a Rome free from the chains of the tyrant. In essence, Sertorius feels himself to be displaced. For Pompée the situation seems to be far less clear-cut, in part because he is based in a camp located in an indefinite space outside of Nertobrige. Spain has become an uncomfortable place for him because he has

\footnotetext{
${ }^{10}$ There are those who might disagree, but such a reading sets aside numerous indicators pointing to Sertorius's centrality: the title of the tragedy, the relative onstage presence of the two men (Pompé is onstage for 512 lines and Sertorius for 1063.5; Pompée only appears in two acts to Sertorius's four) and the number of lines spoken by each (Pompée: 240; Sertorius: 497).

${ }^{11}$ In Pompée's long discussion with Sertorius both men treat Rome like a living being. Pompée asks, "n'est-il aucune voie/Par où je puisse à Rome emporter quelque joie?" (11.921-22); "C'est elle par ma voix, Seigneur, qui vous en prie; /C'est Rome..." (11.926-27). Sertorius responds in a similar fashion, speaking of how Rome has chosen to "revivre ailleurs dans sa première force, /Avec les faux Romains elle a fait plein divorce" (11.933-34).
} 
been unable to defeat Sertorius. Indeed, like Sertorius, Pompée is not where he wants to be. He too yearns to return to Rome ("Il brûle d'être à Rome," says Sertorius, 1.151), but only in order to receive Sylla's permission to go off and fight Mithridate elsewhere (11.149-50). Geographical space for Pompée, thus, is intimately tied to his own glory and ambition; he seeks to go where he will advance his own interests. Rome is first and foremost an arena for his future leadership. Perpenna seems to have even less deeply seated emotional ties to Rome than does Pompée; he will happily remain in Nertobrige, satisfying both his desire and his ambition by becoming Viriate's husband and king. In contrast, Viriate is completely anchored in her kingdom, both physically and emotionally: the interests of Lusitania are the only ones that drive her. She thus most closely resembles Sertorius in her geographic loyalty.

An issue that arises in conjunction with a discussion of geographical space is mobility, the power to move from one space to another. Sertorius is a figure of immobility: he cannot leave Nertobrige, a place that can never be more than Rome in exile. He yearns for the real Rome but is unable to move towards it. Sertorius's immobility is both metaphorical and literal. He is bound on all sides by competing demands: Aristie, Viriate, and Perpenna all want his name, and he is unable to extricate himself from the web of their rival interests. Sertorius's immobility is also based on concrete factors. First, he does not believe Pompée's offer that Sylla will step down to make the peace. While he is much blamed for rejecting the Roman proposition, the context in which it is made-late in the meeting of the two leaders and after numerous barbs have been exchanged-make Sertorius's wariness seem entirely reasonable. Second is his powerful attraction to Viriate, which, if it is to be satisfied, will preclude his return to Rome. It is curious, however, that the geographical consequences for Sertorius of choosing to marry Viriate, as opposed to Aristie, do not surface until act 4, scene 2, when they appear to be part of a cruel, cold-blooded trap on Viriate's part. It does not require a great deal of reflection, however, to recognize that any marriage between Sertorius and Viriate inevitably ties Sertorius to Lusitania. Sertorius's silence on the subject may be attributed to Corneille, and his specific goals for the dramatic confrontation in act 4 scene 2 . Conversely, the silence may be ascribed to Sertorius himself: his love is so compelling that he cannot bring himself to think of the price he will have to pay. The general instead frames a possible union with the queen in terms of its benefits to Rome or in terms of generous sacrifice to his lieutenant. The spatial reality of the situation was present all along, but Sertorius chose to blind himself to it. Indeed, the spatial consequences of this union for Sertorius are reinforced by the Roman opinion of royalty; marrying a queen will exclude Sertorius forever from his homeland, a fact that Viriate drives home: "loin d'y [marriage to a queen] souscrire, /Elle [Rome] en prendra pour vous une haine où j'aspire" (11.1353-54). ${ }^{12} \mathrm{We}$ may thus suggest that Sertorius's blindness to the consequences of marrying Viriate is a sign of mental immobility.

\footnotetext{
12 It is worth noting that there is an exceptional concentration of references to time and space in act 4 scene 2 .
} 
Indeed, it is not going too far to speak in terms of imprisonment. While Sertorius's soldiers left Rome in the name of freedom and he himself calls Rome under Sylla "un enclos de murailles" (1.929) and a "prison" (1.932), in fact Sertorius is made a prisoner by his love for Viriate. In act 4 scene 2 the queen makes the situation clear: "Si vous m'aimez, Seigneur, nos mers et nos montagnes/Doivent borner vos voeux, ainsi que nos Espagnes" (11.1329-30, italics mine). The imprisonment extends to Sertorius's Roman soldiers whom she hopes to "enchainer tous sur les rives du Tage" (1.1361). ${ }^{13}$ The notion of imprisonment will return briefly and far more concretely in the fifth act when Perpenna and Aufide make Viriate a prisoner in her own palace.

In this dramatic universe, movement is difficult or contested. Only in the case of Pompée is this not so; for him there seem to be no walls, no spatial limitations, no borders. He alone enters and leaves and again enters Nertobrige. What enables Pompée to move freely - the truce - doesn't have the same effect on any of the other main characters. Sertorius, Perpenna, Viriate, and Aristie all remain in the city. Pompée's spatial fluidity enhances his stature by suggesting a capacity that others do not have. The geographical setting of Sertorius is associated with exile for all but Viriate. That Pompée alone is able to move freely across its various boundaries is a sign of his adeptness, itself a harbinger of his triumph at the play's conclusion. While he chafes at being in Lusitania, he alone takes steps to move from there. But Pompée's freedom of movement is a two-edged sword, as it functions equally well as a metaphor for his moral elasticity.

Space implies a relation of distance, and in this case it is the distance from Rome that matters. Despite Sertorius's rousing assertions of geographical centrality in the new Rome he has fashioned from his army and his group of exiles_- "Rome n'est plus dans Rome, elle est tout où je suis" (1.936)—his words ring hollow. Pompée too feels lost in the Lusitanian hinterlands, but only because Lusitania has shown itself not to be a place in which he may increase his glory. In fact, the simple fact of being far from Rome works to Pompée's advantage, as he explains to Aristie: "Je sers, mais jusqu'ici l'ordre vient de si loin, /Qu'avant qu'on le reçoive, il n'en est plus besoin" 11.1099-100). The distance from Rome thus provides a means of attenuating Pompée's subservience to Sylla.

Rome remains the magnet that attracts all of the characters (except Viriate), the personified space that defines them and draws them in. Just as the city Rome is given the force and status of an actant, so too is Sertorius made to function as a geographical space. He too is a magnet, drawing others to him: Perpenna's soldiers abandon their general to serve under Sertorius, Aristie and Viriate both want to marry this man whom they do not desire, and even Pompée enters Nertobrige alone and without protection in order to speak with him. ${ }^{14}$

Of course, time and space are not independent of one another. The stage is the domain of the here and now. What Corneille accomplishes in this tragedy is to enrich this present space with the past, the future, and another geographical location. In two respects, he manages to intertwine considerations of time and space, thereby heightening the

\footnotetext{
${ }^{13}$ Ironically, Viriate frames her discussion in terms of their freedom in Lusitania: "La liberté n'est rien quand tout le monde est libre, /Mais il est beau de l'être et voir tout l'Univers [=Rome]/Soupirer sous le joug et gémir dans les fers" (11.1334-36).

14 One might suggest that Pompée is in fact drawn to Aristie at least as much as to Sertorius.
} 
complication engendered by each dimension. The first is the truce, the temporary cessation of hostilities between the two Roman armies. Because it is impermanent, due to end with the coming of spring (1.138), it introduces a break or gap in the temporal continuity of the war. It also changes the conditions of the space in which the characters operate, allowing for a freedom of movement impossible otherwise. While we have seen that four of the characters are nonetheless imprisoned in the geographical space of Nertobrige, Pompée is not the only one to profit from the truce spatially. Sertorius's soldiers have also crossed the boundaries of warfare: "La trêve a dispersé l'armée à la campagne" (1.109). The truce brings with it a kind of pleasing relaxation of boundaries that contrasts with the harsh discipline and restrictions of warfare. Perhaps it is this atmosphere of the truce - a time of spatial openness - that leads Sertorius to declare his love for Viriate. We find a progressive loosening of restraint in this regard: Sertorius merely sighs meaningfully in act 2 ; in act 4 he threatens suicide and then makes his aveu.

The second intertwining of space and time occurs in the fifth act, and involves both its structure and its content. We noted briefly the acceleration of time that act 5 brings, and indeed its hyperactive pace contrasts strikingly with the lengthy political debate of act 3. In this respect act 5 is unlike any other final act in Corneille's oeuvre. Time is not only accelerated however; it is also fragmented and disjointed, as the onstage pair of women receive in rapid succession the visits of individuals coming from a series of different spaces, near, far, and in between. It is no longer the loose, easy geographical space of the truce, but a relational space of frightening and fractured disorder.

Act 5 opens with Aristie and Viriate alone together on stage for the first time. Their meeting has a spatial aspect to it, in that they represent Rome and Lusitania, respectively. It also echoes the encounter two acts earlier between Sertorius and Pompée: representatives of two sides discussing the possibility of resolving their differences. Unlike, the two men, Viriate and Aristie harbor no personal jealousy and almost immediately reach an accord. Their agreement clears the impasse that has been the motor of the plot-whom should Sertorius marry? -and almost magically opens the floodgates of time and space that immediately come crashing in on them in waves of messengers.

The first of these, Arcas, comes from farthest away, from Rome, and the information he announces in act 5, scene 2-that Sylla has given up the throne and Émilie has died in childbirth-comes from the predramatic past. Because of the time needed for this information to travel from Rome to Lusitania, most of the action of the entire play is shown to have been futile. Sertorius no longer needs Viriate's close alliance because he may return to Rome; Aristie no longer has any desire to marry Sertorius for she may return to her husband; Pompée may now enjoy his wife and furthermore, his servitude to a tyrant has come to an end; even Perpenna's scheme to kill Sertorius makes little sense as the frontier isolating Lusitania falls. ${ }^{15}$ The road to Rome is not only open, but gives the impression of being foreshortened as well. Only for Viriate have the stakes not changed radically;

\footnotetext{
15 In d'Aubignac's estimation, had the news of Sylla's abdication arrived just a half-hour earlier, the conspirators would not have dared to assassinate Sertorius because of fear of Pompée, whose arrival would have been imminent (1995, p. 37).
} 
she still wants an alliance through marriage with Sertorius, but she understands immediately upon hearing the messenger's news that such a union will not come to pass. It is a powerful irony that the time needed to cover the space separating Rome and Nertobrige with news of Sylla's abdication and Émilie's death upends and virtually expunges the temporal span of the play. Racine will make very similar use in Bajazet (1672) of the distance between Byzance and Amurat's battle camp outside of Babylon.

The discussion of the ramifications of the letter from Rome is soon interrupted by Thamire's announcement of the assassination of Sertorius (5.3). The combination of the two reports constitutes an accumulation of shocking events, which, while not entirely unprepared, are certainly not expected, especially in such rapid succession. More to the point, the second and third scenes of this final act juxtapose thoroughly opposing geographical spaces and moments in time. The news concerning Sylla and Émilie comes from far away, while Thamire's announcement of Sertorius's death comes from the feast at Perpenna's nearby residence. From the perspective of the two women, isolated in the prison-like space of the stage, everything occurs elsewhere; yet the extreme distance separating the spaces from which the messages come creates a dizzying effect. The shock of the juxtaposed temporal realms is equally powerful: Sylla stepped down and Émilie died perhaps weeks earlier, while Sertorius was killed only a matter of minutes before Thamire's stage entrance; all of these events, however, rush on stage in rapid-fire succession, as though virtually contemporaneous. ${ }^{16}$

The nature of the onstage space undergoes significant alterations in the course of the final act. In the first scene, it is a private meeting place in which Aristie graciously cedes Sertorius to Viriate. Once the wave of announcements of events transpiring elsewhere begins, however, the women's onstage setting becomes one of isolation and irrelevance, reminiscent of Camille and Sabine in Horace, as the two are buffeted by important events from which they are at a temporal and spatial remove. In act 5 scene 4 the action returns to the stage in the person of Perpenna. In what is by far the longest scene of the fifth act, there is a struggle between him and the women, a struggle that has both spatial and temporal components. It is understood, because of what Thamire says at the end of the preceding scene that Perpenna has in fact imprisoned the women ("Aufide, /Des portes du palais saisi pour ce perfide [Perpenna], /En fait votre prison," 11.1689-91). He enters in the role of the triumphant warrior who is now in charge, but both women refuse him the status that he claims and obviously craves. In response to their hostility-Aristie threatens him with reprisal from Pompée and Viriate promises to murder him if forced to marry him-Perpenna has recourse to both place and time. Interestingly, he is highly limited in both regards. He responds to Aristie by telling her that she will serve as his hostage in negotiating with Pompée, thus stressing her spatial restriction, but indicating that it is of a temporary nature. A hostage differs from a prisoner because it is understood that the former is likely to go free provided certain conditions are met. With Viriate as well, Perpenna accepts a narrow time frame, so desperate is he to take hold of everything he feels Sertorius kept him from: "Et n'eût

\footnotetext{
16 It may be worth noting that, historically, Sylla's abdication and Sertorius's death were separated by years, not weeks (see Kerr 1983, p. 27). Their juxtaposition is thus a deliberate choice on Corneille's part.
} 
tout mon bonheur que deux jours à durer, /Vous n'avez dès demain qu'à vous y [for marriage] préparer" (11.1799-1800). ${ }^{17}$ Perpenna's limitations foreshadow his imminent demise, which is in fact even more imminent than Viriate's or Aristie's threats suggest. The brutally ephemeral nature of time as it relates to Perpenna is underlined with subtlety and skill by Corneille in his use of interruption. Sertorius's assassin tells Viriate: “J'accepte votre haine, et l'ai bien méritée, /J'en ai prévu la suite, et j'en sais la portée. /Mon triomphe..." (11.1801-3). His final words are interrupted by the arrival of a bloody Aufide. The words "mon triomphe" are thus doubly ironic, first and most obviously because any triumph he might feel is interrupted, but also because he is so clearly aware that he will not be allowed to enjoy his triumph, whether it be political or sexual, for any length of time. ${ }^{18}$

Like Arcas and Thamire, Aufide is a messenger, albeit a rather dramatic one, as he is mortally wounded. In terms of relational space, we find a progression in the three messengers and the distance they covered to come on stage, from far to near to just offstage. The news Aufide brings is both expected-Pompée is coming-and surprising-Pompée has effortlessly and instantaneously taken control of the city. Perpenna, almost immediately after taking power, loses it all to Pompée. "La porte s'est ouverte à son [Pompée's] nom" (1.1805), Aufide tells Perpenna. Corneille is clearly signalling that Pompée replaces Sertorius as a great leader through the use of the power of "son nom". This line reminds the spectator of the force of Sertorius's "nom" that aroused envy in Perpenna at the beginning of the play. ${ }^{19}$

It is only when Pompée arrives on stage (5.6-7) that a new order can begin to form. He slows the onslaught of time and space in this fifth act, offers peace to Viriate, and brings justice by having Perpenna killed. Indeed, when Celsus returns in the final scene to inform Pompée of Perpenna's death, he, unlike the three other messengers, hardly makes an impression. Most important, with the arrival of Pompée all spatial barriers are abolished: Viriate and Aristie are no longer prisoners, and the geographical space between Nertobrige and Rome, like the metaphorical space between the divorced Aristie and Pompée, seems to evaporate as all obstacles are removed.

Spatially, the play ends on a high note. Indeed, Pompée is spatially heroic, overcoming frontiers and limits, moving quickly to bring unity and harmony to all. Why then is he not the hero of the play? In my opinion, he falls considerably short of the mark in terms of time. While Pompée is certainly the beneficiary of "good timing," and obviously the only general left standing at the end, he has no agency in the coincidence of his presence and Sylla's abdication. ${ }^{20}$ Much more important, in

\footnotetext{
17 Doubrovsky discusses Perpenna's attitude in this scene as "la tentation vertigineuse et délétère de l'instant" and the attraction of "l'intensité de l'éphémère" (1963, p. 350).

18 Corneille again makes Perpenna the victim of cruelly ironic interruption in scene 7 when he has Pompée interrupt the récit of Perpenna's death. The récit starts out impressively enough ("le perfide/A vu plus de cent bras punir son parricide," 1.1908-09), but after only two lines Pompée interjects: "Il suffit" (1.1912), thus depriving Perpenna of the classic death récit.

19 The entire line reads "La porte s'est ouverte à son [Pompée's] nom, à son ombre” (1.1805). The word "ombre" carries significant poetic weight here. It refers first to the mere hint of Pompée's impending arrival. But the word "ombre" also refers to the dead, specifically, because of the juxtaposition with "son nom," to Sertorius. The link between the two leaders is thus reinforced doubly in this line.
}

${ }^{20}$ Bilezekian notes that "Ni fusion ni régénération morale ne résulteront du dénouement où Pompée 'bénificiera' d'une part de l'abdication de Sylla ... et d'autre part de l'assassinat de Sertorius” (1989, p. 2). 
terms of time, is Pompée's past. His morally questionable accommodations with Sylla cannot be overcome in the same fashion as the physical division between the two Romes. Aristie's pardon and willingness to return to Pompée are indicative of her virtue and her love, but do not suffice to absolve him in the eyes of the spectator.

Corneille remains perfectly mute on the subject of Pompée's moral standing, in no way tarnishing the general's arrival in the fifth act, his rescue of the imprisoned women, his meting out of justice to Aufide and Perpenna, and his generous offer of peace to Viriate. All the same, one cannot help but hark back to Pompée's only other appearance in the play (Act 3) and his meeting with Sertorius, a meeting of two great leaders, of course, but one in which Sertorius comes out ahead. Sertorius's superiority in that scene is visible in the generosity of his offer to serve under Pompée, in the tactical acumen of his use of Aristie in discussion with Pompée, and in Pompée's clumsy timing in making Sylla's offer of peace. McDermott notes: "[b]efore their meeting the triumph of Sertorius over Pompée had been military only; after their debate it is clear that Sertorius is moral victor as well" (1983, p. 116). The absence of Sertorius at the crucial moment of the fifth act, due entirely to the coincidental timing of his death, is Corneille's subtle way of undermining Pompée. We cannot help but wonder what the final scene would look like were Sertorius still alive. Sertorius's heroism, as we noted earlier, belongs to the predramatic past. Pompée's present and future may be heroic, but his past—which includes acts 1 to 4 -is sullied, and Corneille suggests that he can not transcend that past.

For Corneille each play is an opportunity for experimentation, an approach that Forestier calls "une dramaturgie de la gageure," and in Sertorius, an ambitious, magnificent, and flawed tragedy, one of the challenges that Corneille set for himself was to explore the possibilities of time and space. Indeed, Sertorius is strikingly different from all of the playwright's other plays in that both dimensions are starkly foregrounded. While d'Aubignac's criticism of the play-that five main stories or plots are too many for a play (1983, p. 31) — may be valid, while Pocock may have a point in suggesting that the characterization of Perpenna does not cohere (1973, p. 121), and while Butler may indeed be correct in finding that Sertorius bears a problematic resemblance to a comic character (1977, pp. 66-67), Corneille's dramatic use of both time and space is masterful. These two dimensions highlight numerous dimensions of the play, explain Pompée's inadequacy as a hero, as well as his claims to that title. Most importantly, Sertorius's tragedy is conveyed through time and space. He is a man who has run out of time and space; he dies before he can move either figuratively or literally.

\section{References}

Bilezikian, M. (1989). Divorce, désordre et légitimité dans Sertorius de Corneille. Cahiers du dixseptième, 3(2), 1-16.

Butler, P. F. (1977). Sertorius: comédie tragique. In H. T. Barnell (Ed.), The classical tradition in French literature: Essays Presented to R. C. Knight London: Grant and Cutler (pp. 61-70).

Couton, G. (1987). Notice to Sertorius by Pierre Corneille. In G. Couton (Ed.), Euvres complètes. Paris, Gallimard. (pp. 1440-1450). 
d'Aubignac (1995). Dissertations contre Corneille. In N. Hammond \& M. Hawcroft (Eds.). Exeter: University of Exeter Press.

Doubrovsky, S. (1963). Corneille et la dialectique du héros. Paris: Gallimard.

Forestier, G. (1985). Une dramaturgie de la gageure. Revue d'Histoire Littéraire de la France, 5, 811819.

Fumaroli, M. (1996). Pierre Corneille, fils de son oeuvre. In Héros et orateurs. Geneva: Droz. (pp. 17-61).

Kerr, C. B. (1983). Temps, lieux et paradoxes dans Sertorius. Revue d'Histoire Littéraire de la France, $83,15-28$.

Lasserre, F. (1998). Sertorius (1662). In M. Vuillermoz (Ed.), Dictionnaire analytique des oeuvres théâtrales françaises du XVII siècle (pp. 679-82). Paris: Champion.

McDermott, H. B. (1983). Heroism and tragedy: Corneille's Sertorius. Kentucky Romance Quarterly, 30, 113-22.

Pocock, G. (1973). Corneille and Racine: Problems of the tragic form. Cambridge: Cambridge University Press.

Prigent, M. (1986). Le Héros et l'état dans la tragédie de Pierre Corneille. Paris: Presses Universitaires de France.

Stegmann, A. (1968). L’Héroïsme cornélien. Paris: Armand Colin. 